\title{
The Structure of Address, Personal Pronouns and Proclitic As Honorific Markers In Taba Language, East Makean Island, South Halmahera
}

\author{
Hujaefa Hi Muhamad ${ }^{1}$, Wakit Abdullah², Dwi Purnanto ${ }^{3}$, Sri Marmanto ${ }^{4}$ \\ \{hujaefamuhammad16@gmail.com\} \\ Doktorate Program in Linguistics, Universitas Sebelas Maret,JL.Ir Sutami36 A, Surakarta 57126 \\ Indonesia
}

\begin{abstract}
Greetings and personal pronouns in Taba language cannot be separated from the cultural context and social backgrounds, such as age, kinship, and relative statuses including education level, community and religious figures. This study aims at analyzing the patterns of using kinship greetings with honorific personal pronouns. This study was conducted on Taba speakers, the people of East Makeang Island, South Halmahera. The data were taken from speeches of sentences containing greetings for kinship and honorific personal pronouns through observation and recording. The results show that the use of greetings determines the lexicon of honorific and non-honorific personal pronouns. A second person singular will form an honorific in second personal plural pronoun. This also applies to third-person greetings. Second and third plural pronouns followed with proclitic are morphologically attached to the verbs and cross-referenced with pronominal pronouns/phrases in syntactic relation/function as the subject.
\end{abstract}

Keywords: honorific, Taba language, address, personal pronouns

\section{Introduction}

Greeting is an important linguistic instrument in communication. Greeting is used to state intimacy, show politeness and establish a formal atmosphere. Greeting is established from morphemes, words, or phrase used to refer each other in different conversational situation by speakers' relationship characteristics [1]. The conversational situation is influenced by social factors, such as age, sex, kinship, and social status) and situational factors, such as who, when, where and communicational situation used [2]. Greeting is also used to represent social class, gender, age, religious place, etc. [3]. Since each language has their respective social and cultural background, the greeting system of each language will be different. Such different background will influence the grammatical structure, including lexicon, morphology, syntax and semantics.

The use of greeting in spoken sentence is commonly in combination with personal pronoun. The two form a structure in which the lexicon of personal pronouns is influenced by the term of address they refer to. Personal pronoun refers to oneself, listener and person spoken of [4]. In a sentence of address, the personal pronoun used is second-person pronoun, since sentence of address is only used in direct oral communication, while oral communication only occurs between a first person and a second person with a communication started by the first person greeting the second person. Therefore, second-person pronoun will emerge in term of address. 
This research focuses on terms of address in family. Family is a social system with important role in instilling values and shaping individual's habits, behaviours and character in wider social interaction [5]. Therefore, family has the most important effect on introducing the use of pattern of address and personal pronoun. In the connection between term of address and personal pronoun, Honorifics are a system to mediate the two. An honorific system has certain functional level allowing users to consider any language use aspects. Honorifics are used to maintain smooth communication for reciprocity between speaker and listener. An honorific speech is the form of politeness aiming at respecting the interlocutor [6].

The research data were Taba language (hereinafter BT). BT is one of the Austronesian languages used in the eastern part of Makeang Island, South Halmahera, North Maluku Province [7]. BT has 20,000 speakers distributed in South Halmahera Regency, including Makeang district, Kayoa district, West Gane district, East Gane district and some regencies out of North Halmahera, Central Halmahera Regency, East Halmahera Regency and Moti district of Ternate Municipality [8]. Taba language was initially only spoken by the people of the eastern part of Makeang Island.

However, its area of use has spread since its speakers have migrated to new areas, both through governmental programs and their own initiative covering a number of villages in East Bacan and West Bacan, along West Gane coast, Malifut, North Halmahera, some villages in West Halmahera, one or two villages in East Halmahera, some villages in Oba district of Tidore City, and one village on the east coast of East Gane district of South Halmahera. Makeang Island is an area of South Halmahera Regency which is divided into two districts, namely: Inner Makeang Island (Taba) and Outer or Western Makeang Island (Moi/likil) districts. The addresses which will be described below are those of Taba language in Waigitang-Waikyon dialects.

The forms of address of Makeang/Taba ethnic in Inner Makeang Island district are divided into kinship address, general address, customary/title address, religious address and position or profession address. These forms of address refer to [9] and [10], in which the forms of the concerned address are kinship and non-kinship address. Kinship address is divided into vertical kinship and horizontal kinship. Research on BT have been reported by some researchers, such as [7], [8], [11], [12] and [13]. Research on terms of address of local language have been conducted, such as of Javanese terms of address [14] and of religious domain [3]. Research on honorifics have also been conducted by [15], [16], [17] and [18]. Some of the research still leave gap, particularly ones focusing on three studies of BT, namely term of address, honorific and proclitic.

\section{Research Methods}

The research data were speech in the sentence Kanglolo Abubakar, meu htulu hu te which was taken from the recording of BT speaker, Makeang Island, South Halmahera, North Maluku Province. The speech was chosen since the speaker and the listener were in kinship. In addition, the speech contains term of address, second-person pronoun, and proclitic which are the focuses of the study. The research analysed the data with morphosyntactic analytical stages with the speeches covering term of address, second-person pronoun, and proclitic.

This analysis was used to view various forms of mayor, minor and elliptical sentences. The researcher also applied cross reference analysis to view the meaning of reference to the construction of second-person pronoun and proclitic so as to view the reference structure from 
major to minor sentences. The researcher applied social analysis of morphosyntactic construction so as to view which social relational factors are involved in the honorific construction.

\section{Results and Discussion}

The research data were speech in the sentence Kanglolo Abubakar, meu htulu hu te which was taken from the recording of BT speaker, Makeang Island, South Halmahera, North Maluku Province. The speech was chosen since the speaker and the listener were in kinship. In addition, the speech contains term of address, second-person pronoun, and proclitic which are the focuses of the study. The research analyzed the data with morphosyntactic analytical stages with the speeches covering term of address, second-person pronoun, and proclitic.

This analysis was used to view various forms of mayor, minor and elliptical sentences. The researcher also applied cross reference analysis to view the meaning of reference to the construction of second-person pronoun and proclitic so as to view the reference structure from major to minor sentences. The researcher applied social analysis of morphosyntactic construction so as to view which social relational factors are involved in the honorific construction.

\subsection{Morphosyntax and cross references in sentence of address}

The morphosyntactic structure of BT term of address considers four elements, namely egoistic term of address, personal name, personal noun and proclitic. The structure forms a unitary honorific system in speech.

(1) Kanglolo Abubakar meu htulu hu te.

(2) *Kanglolo Abubakar au mtulu hu te.

Sentence (1) marks the morphosyntactic structure with grammatical pattern, while sentence (2) with non-grammatical structure. The difference between the two sentences may be observed from the structure of personal noun and proclitic accompanying the egoistic term of address.

Table 1. Morphosyntactic structure of egoistic address Speech

\begin{tabular}{|c|c|c|c|c|c|c|}
\hline \multicolumn{7}{|c|}{ Kanglolo Abubakar meu htulu hu te } \\
\hline Kanglolo & Abubakar & meu & $h$ - & tulu & $h u$ & te \\
\hline $\begin{array}{l}\text { Uncle } \\
\text { (Big brother } \\
\text { of father) }\end{array}$ & Personal name & (you) & Marker & come by & & \\
\hline $\begin{array}{l}\text { Egoistic term } \\
\text { of address }\end{array}$ & & $\begin{array}{l}\text { P2J. } \\
\text { Hon. }\end{array}$ & Prok.P2J. Hon & verb & ASP & $\begin{array}{l}\mathrm{NE} \\
\mathrm{G} \\
\end{array}$ \\
\hline \multicolumn{7}{|c|}{ 'Uncle Abubakar, (you) please come by } \\
\hline $\begin{array}{l}\text { P2T } \\
\text { P2J } \\
\text { Fam } \\
\text { Hon }\end{array}$ & \multicolumn{6}{|c|}{$\begin{array}{l}\text { : second-person singular pronoun } \\
: \text { second-person plural pronoun } \\
: \text { familiar } \\
: \text { honorific }\end{array}$} \\
\hline
\end{tabular}




$$
\begin{array}{ll}
\text { Prok } & \text { : proclitic } \\
\text { ASP } & \text { : aspect } \\
\text { NEG } & \text { : negative }
\end{array}
$$

The speech situation above requires the speaker (niece/nephew) to address the listener (uncle) honorifically. Kanglolo is the term of address addressed to an uncle, big brother of father. Kanglolo is generally in combination with personal name. This combination shows clear identity of the referred uncle to distinguish reference for another uncle. In addition, personal name attached to Kanglolo also aims at building honorific. This system is the marker of other functional structure in speech in support of honorifics in egoistic term of address Kanglolo Abubakar, which is personal noun and proclitic.

Sentence (1) uses meu as the second-person pronoun. Lexicon mеu is the form of secondperson honorific plural pronoun (P2J.Hon.) referring to the phrase Kanglolo Abubakar. When the term of address Kanglolo Abubakar appears, second-person singular pronoun (P2T) which should refer to the singular term of address changes to plural (P2J). This change to plural is the honorific marker resulting from the egoistic term of address which appears.

The emergence of meu causes the verb tulu affixed by proclitic $h$-. Proclitic $h$ - serves as proclitic marker of second-person plural pronoun (Prok.P2J). The appearance of proclitic $h$ - is the marker in support of honorific built by P2J mеи. The description of honorific pattern of sentence (1) is presented in the structure below.

Term of address (ego) + Name $\rightarrow$ P2J.Hon. $\rightarrow$ Prok.P2J.Hon. (+Verb)

The morphosyntactic pattern contains the sequence of honorific system. The sequence may be checked through a cross reference analysis. The sequential pattern between the lingual units is presented in the analysis below.

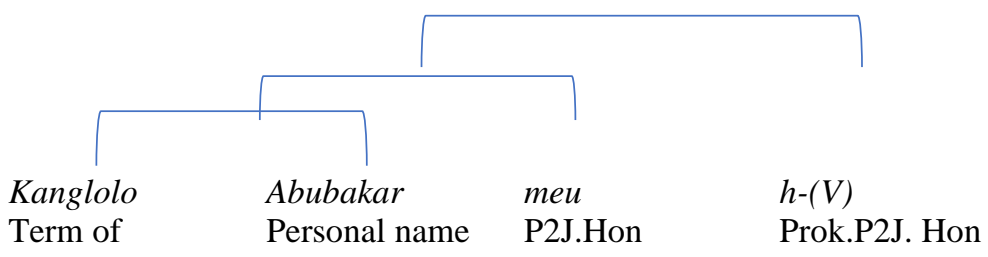

According to the cross reference analysis, the term of address Kanglolo is referred to by personal name Abubakar and forms core-attributive phrasal structure. Abubakar serves to mark two things: as identity to explain the person referred to and as support for honorific Kanglolo. The phrase Kanglolo Abubakar is referred to by P2J.Hon. meu. Lexicon meu appears as the result of egoistic term of address appearing in front of it and marks the honorific. In BT, secondperson singular pronoun referring to egoistic term of address changes to plural form as the honorific marker. Proclitic $h$ - becomes the marker of honorific verb as the result of previous construction, which is meu.

The appearance of meu makes the morphological structure after it to form Prok.P2J.Hon. $h-$. This is the grammatical system in honorific pattern in kinship address speech containing egoism. Besides the pattern of sentence (1), the grammatical form is also found in sentences (3) and (4) with the use of ellipsis. The ellipsis marks the previous pragmatic context. Although (3) and (4) are in the form of ellipsis, the principle remains showing grammaticalization. 
(3) Kanglolo htulu hute.

(4) Htulu hu te.

Sentences (3) and (4) are minor sentences with some syntactic functions having ellipsis. In analysis, the morphosyntactic structure may be observed in the description below.

Table 2. Model 1 of elliptic grammatical construction of sentence of address

\begin{tabular}{lllllll}
\hline \multicolumn{2}{l}{ Kanglolo htulu hu te. } & & & & & \\
\hline Kanglolo & $\bar{\varnothing}$ & $\bar{\varnothing}$ & $h$ - & tulu & hu & Te \\
\hline Uncle & $\begin{array}{l}\text { Ellipsis of } \\
\text { Personal name }\end{array}$ & $\begin{array}{l}\text { Ellipsis of } \\
\text { 'you' }\end{array}$ & Marker & come by & & \\
\hline $\begin{array}{l}\text { Egoistic } \\
\text { term of }\end{array}$ & P2J. Hon. & Prok.P2J. Hon & verb & ASP & NEG \\
address & & & & & & \\
\hline 'Uncle, come by.' & & & & & & \\
\hline
\end{tabular}

Table 2 shows morphosyntactic construction resulting from ellipsis. Despite some elliptic syntactic functions, the pattern is grammatical. The cross-reference analysis may be observed in the description below.

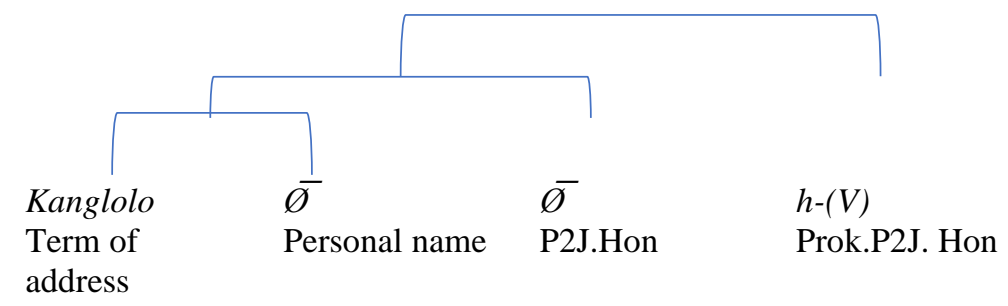

Therefore, the ellipsis forms minor sentence with intact syntactic function. This may be viewed from the non-reduced message of speech which may still be caught by the listener. The honorific construction may be observed with markers Kanglolo and Prok.P2J.Hon. $h$-.

Table 3. Model 2 of elliptic grammatical construction of sentence of address

\begin{tabular}{|c|c|c|c|c|c|c|}
\hline lu hu te. & & & & & & \\
\hline $\bar{\varnothing}$ & $\bar{\varnothing}$ & $\bar{\varnothing}$ & $h$ - & tulu & $h u$ & te \\
\hline Ellipsis of Uncle & $\begin{array}{l}\text { Ellipsis of } \\
\text { Personal name }\end{array}$ & $\begin{array}{l}\text { Ellipsis of } \\
\text { 'you' }\end{array}$ & Marker & come by & & \\
\hline $\begin{array}{l}\text { Egoistic term of } \\
\text { address }\end{array}$ & & P2J. Hon. & Prok.P2J. Hon & verb & ASP & $\begin{array}{l}\mathrm{NE} \\
\mathrm{G}\end{array}$ \\
\hline
\end{tabular}

Table 3 shows the most extreme morphosyntactic construction. Ellipsis occurs to three syntactic functions, namely term of address, personal name and P2J.Hon. Honorific marker is only found with Prok.P2J.Hon $h$-. The cross-reference analysis may be observed in the description below. 


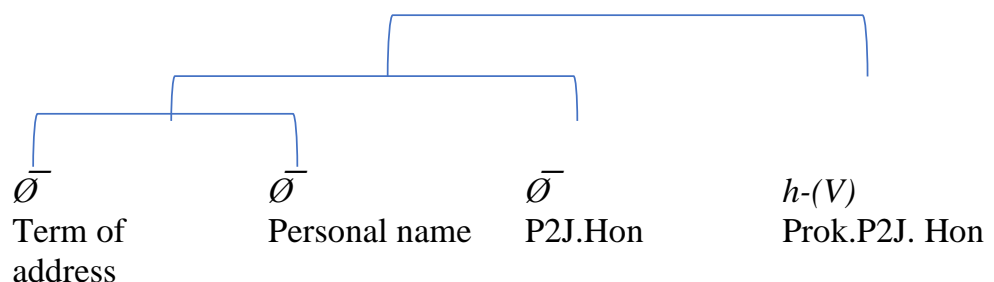

Therefore, the ellipsis forms minor sentence with intact syntactic function, thus the message of speech may still be caught by the listener. As a note, pragmatic context greatly influences the meaning of message. To view the non-grammatical form of honorific pattern of egoistic address speech, the description below presents the differences.

Table 4. Morphosyntactic structure of non-grammatical sentence of address

\begin{tabular}{|c|c|c|c|c|c|c|}
\hline \multicolumn{7}{|c|}{ Kanglolo Abubakar au mtulu hu te } \\
\hline Kanglolo & Abubakar & $a u$ & $m-$ & tulu & $h u$ & te \\
\hline $\begin{array}{l}\text { Uncle } \\
\text { (Big brother } \\
\text { of father) }\end{array}$ & $\begin{array}{l}\text { personal } \\
\text { name }\end{array}$ & (you) & marker & come by & & \\
\hline $\begin{array}{l}\text { Egoistic term of } \\
\text { address }\end{array}$ & & P2T.Fam. & $\begin{array}{l}\text { Prok.P2T } \\
\text { Fam }\end{array}$ & verb & ASP & NEG \\
\hline
\end{tabular}

'Uncle Abubakar, please come by'

The construction above is the non-grammatical form, since the egoistic term of address Kanglolo Abubakar is referred to using P2T.Fam. $a u$. In BT, P2T au is used for familiar term of address, such as friend of relative in which the speaker has egoistic status equal to or higher than the listener greeted. The second-person singular pronoun triggers appearance of Prok.P2T.Fam. $m$ - affixed to the verb tulu.

\subsection{The influence of social factors on the morphosyntactic principle of Honorific speech structure}

The difference in social factor triggers honorific. Term of address is the basic reason whether or not honorific morphosyntactic structure is built in which personal noun and proclitic exist as markers in sentence construction. In BT, the social factor is determined with age, kinship, figure element and relative status within which there are education, profession and material elements. The social status may appear once or in combination. With less or more combination of social status, the honorific will form the same morphosyntactic construction. The reason is that in BT there is no speech level like in Javanese language with its krama, madya and ngoko, thus more combinations of social status will form different honorific gradation. Below is the chart of analysis of honorific principle of speech structure of term of address, personal noun and proclitic. 


\begin{tabular}{|c|c|c|}
\hline $\begin{array}{c}\text { Second-Person Singular } \\
\text { Pronoun } \\
a u \\
\text { "you (singular)' }\end{array}$ & $\underset{\substack{\text { Age } \\
\text { Kinship }}}{\downarrow}$ & $\begin{array}{l}\text { Second-Person Plural } \\
\text { Pronoun } \\
\text { meu } \\
\text { 'you (plural)' }\end{array}$ \\
\hline $\begin{array}{c}\text { Proclitic Second-Person } \\
\text { Familiar Singular } \\
\text { Pronoun } \\
m-\end{array}$ & $\begin{array}{c}\text { Figure Element } \\
\text { Relative Status } \\
\text { (education, profession, } \\
\text { material) }\end{array}$ & $\begin{array}{c}\text { Proclitic Second- } \\
\text { Person Honorific Plural } \\
\text { Pronoun } \\
h-\end{array}$ \\
\hline
\end{tabular}

\section{Conclusion}

The term of address of kinship element in BT is the basis of formation of morphosyntactic structure in sentence, particularly in its influence on the presence of personal name, secondperson pronoun and proclitic. Personal name exists to refer to the identity and honorific. In addition, second-person plural pronoun exists to replace single personal noun as the honorific marker of term of address referred to. Besides, proclitic second-person plural pronoun appears as honorific marker, thus in morphosyntactic construction, this proclitic exists to accompany verb. This construction forms the grammatical structure of honorific sentence in mayor sentence.

In minor sentence, the elliptic element of syntactic function in elliptic pattern does not influence sentence grammaticalization. The ellipsis may be realized in term of address, personal name and personal noun. The ellipsis appears as the result of existing context; thus speaker and listener have the same schemata, thus despite ellipsis, the meaning of speech may still be received. This may also be observed in cross reference analysis to prove whether or not the ellipsis influences the grammatical function. Social factor plays a great role in the existence of honorific, such as age, kinship, figure element and relative status. The difference in one social relationship is sufficient to apply honorific construction. The combination of social aspect also does not influence honorific gradation, since BT does not have speech level like Javanese language does.

\section{References}

[1] H. Kridalaksana, Kamus Linguistik Edisi Keempat, Keempat. Jakarta: Gramedia Pustaka Utama, 2013.

[2] Soewito, Pengantar Awal Sosiolinguistik Teori dan Problema. Surakarta: Surakarta UNS Press, 1983.

[3] E. Herniti, "Sapaan dalam Ranah Keagamaan Islam (Analisis Sosiosemantik)," Thaqafiyyat, vol. 15, no. 1, pp. 22-38, 2016.

[4] H. Alwi, Tata Bahasa Baku Bahasa Indonesia. Jakarta: Balai Pustaka, 2003.

[5] Surahmat and E. Rafiqoh, "Kata Sapaan pada Masyarakat Pantai Utara Jawa: Studi Kasus di Kabupaten Kendal,” In Kata Sapaan Pada Masyarakat Pantai Utara Jawa : Studi Kasus Di Kabupaten Kendal, 2020, no. March, pp. 65-77. 
[6] M. N. Zaman, M. R. Nababan, and Djatmika, “10.18592/khazanah.v16i1.2130,” Khazanah J. Stud. Islam dan Hum., vol. 16, no. 1, pp. 125-142, 2018, doi: 10.18592/khazanah.v16i1.2130.

[7] Burhanuddin, Mahyuni, and Sukri, "Refleks Pan ke dalam Bahasa Taba: Langkah Awal Menguji Hipotesis Adriani \& Kruyt ( 1914 ),” Leksema J. Bhs. dan Sastra, vol. 4, pp. 85-96, 2019.

[8] H. H. Muhamad, "Sapaan dalam Bahasa Taba Di Pulau Makeang Kabupaten Halmahera Selatan," Universitas Negeri Yogyakarta, 2011.

[9] J. Amir, "Sapaan dalam Bahasa Bugis Dialek Sidrap," Linguist. Indones., vol. Februari, no. 2011, pp. 69-83, 2011.

[10] L. Safyahya, Aslinda, Noviantri, and Efriyades, Kata Sapaan Bahasa Minangkabau di Kabupaten Agam. Jakarta: Badan Bahasa Departemen Pendidikan Nasional, 2000

[11] J. Bowden, "Taba: description of a South Halmahera language," Pacific Linguist., vol. 521, 2001, doi: 10.15144/PL-521.cover.

[12] Burhanuddin, "Inovasi Internal Bahasa Taba di Maluku Utara: Perspektif Linguistik Historis," Humanus, vol. 16, no. 2, pp. 239-247, 2017, doi: 10.24036/humanus.v16i2.8293.

[13] R. Habsi, "Penggunaan Sapaan Kekerabatan Bahasa Makean Dialek Samsuma di Desa Samsuma Kecamatan Malifut," Kaji. Linguist., vol. 1, no. 2018, pp. 52-65, 6AD.

[14] Sulistyowati, “Alternasi Sapaan Bahasa Jawa di Keraton Yogyakarta," Humaniora, vol. 20, no. 2, pp. 168-178, 2008, doi: 10.22146/jh.v20i2.934.

[15] Erni, “Jurnal Bastra (Bahasa dan Sastra) E-ISSN: 2503-3875 E-Jurnal Pendidikan Bahasa dan Sastra Indonesia FKIP UHO," Bastra, vol. 2, no. 1, 2016.

[16] B. Heine and K. Song, "On the grammaticalization of personal pronouns," no. June 2018, 2011, doi: 10.1017/S0022226711000016.

[17] S. Song, "Representing Honorifics via Individual Constraints," pp. 57-64, 2015.

[18] D. Saputry, "sistem honorifik bahasa lampung.pdf," J. Penelit. dan Eval. Pendidik., vol. 7, no. 1, 2005. 